\title{
THE DREAM OF AN ISLAMIC STATE: \\ FROM ISLAMIC POLITICAL MOVEMENT OF AL-IKHWAN INTO ISIS
}

\author{
Istadiyantha, \\ istadiyantha@staff.uns.ac.id \\ Faculty of Cultural Sciences, \\ Universitas Sebelas Maret, Surakarta, Indonesia
}

\begin{abstract}
Abstrak
Timur Tengah merupakan pusat keagamaan bagi muslim di seluruh dunia, termasuk Indonesia. Hubungan keagamaan antara Islam dan Timur Tengah mencakup proses politik dan sejarah yang kompleks. Perjuangan Islam puritan di era dominasi nilai imperialisme dan nilai kebaratan merupakan alasan utama penyebaran gerakan-gerakan politik Islam di berbagai belahan benua Asia. Tujuan penelitian ini untuk menguji hubungan antara gerakan politik Islam di Timur Tengah dan gerakan-gerakan yang telah berkembang di Innesia. Terdapat beberapa aspek yang perlu dipahami mengenai munculnya gerakan-gerakan politik Islam. Penyebaran gerakan-gerakan politik Islam di Indonesia telah menunjukkan perubahan signifikan sejak tahun 1970-an dan 1980-an. Perkembangan gerakan-gerakan politik Islam mulai memperoleh momentum seiring meningkatnya jumlah pelajar dan mahsiswa Indonesia yang belajar ke Timur Tengah, yang menyebabkan eratnya hubungan Indonesia dan Timur Tengah pada banyak aspek. Pada tahun 1980-an, pelajar dan mahasiswa Indonesia di Arab Saudi, Mesir dan negaranegara Timur Tengah lainnya menyerap berbagai ide terkait politik Islam atau gerakan fundamentalis Islam dari Timur Tengah.
\end{abstract}

Kata kunci: penyebaran, gerakan politik Islam, fundamentalisme Islam, teror, Timur Tengah.

$$
\begin{aligned}
& \text { ملخص } \\
& \text { تمثل الشرق الأوسط مركزا دينيا للمسلمين في جميع أنحاء العالم ، وفن إندونيسيا بوجه أخص ـ وتشمل العلاقة } \\
& \text { الدينية بين الإسلام والشرق الأوسط على عمليات سياسية وتاريخية معقدة ـ وكان من أهم عوامل انتشار الحركات } \\
& \text { الإسلامية السياسية في أنحاء العالم كفاح الإسلام الأصولي فن عصر هيمنة القيم الاحتلالية والتقاليد الغربية . } \\
& \text { يهدف هذا البحث إلى تناول العلاقات بين الحركات الإسلامية السياسية في الشرق الأوسط والحركات الإسلامية } \\
& \text { المنتشرة حاليا في إندونيسيا ـ وقد دل انتشار الحركات الإسلامية السياسية فن إندونيسيا على تغيرات واضحة منذ }
\end{aligned}
$$

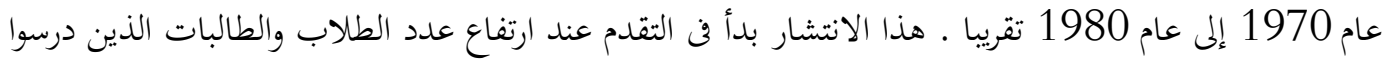

$$
\begin{aligned}
& \text { في الشرق الأوسط مما جعل رسوخ العلاقة بين إندونيسيا والشرق الأوسط فن كثير من الجوانب ـ في عام الثمانيات } \\
& \text { من القرن الماضى أخذ هؤلاء الطلاب كثيرا من الأفكار المتعلقة بالإسلام السياسي أو الحركات الأصولية من قوادها }
\end{aligned}
$$

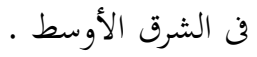


الكلمات المفتاحية : انتشار ، الحركات الإسلامية السياسية ، الأصولية الإسلامية ، إرهاب ، الشرق الأوسط .

\section{INTRODUCTION}

The term political Islam was made popular by Oliver Roy in his book entitled L'échecde l'islampolitique or The Failure of the Political Islam. The term used in this research is Islamic Political Movements, which is equivalent to the term Islamic Fundamentalism. In addition to the term Islamic Political Movements, this article also uses other terms, such as Fundamentalist Islam, Militant Islam, and Radical Islam, but the use of the term Islamic Political Movements is more dominant and is the term chosen for use by the writer because it has been agreed upon by experts both in Indonesia and internationally (Roy, 1996, Istadiyantha, $20 \mathrm{xx}$ ) as the appropriate term to replace the term Islamic fundamentalism. Hassan Hanafi, in his book entitled Al-Ushūliyah al-Islāmiyah, states that Islamic fundamentalism is the 'prototype' of the Salafi movement which was originally led by Ahmad bin Hanbaland subsequently continued by Ibnu Taimiyah, Ibnul Qayyim, and Jamaludin al-Afghani (Hanafi, 1989). In recent times, one of the more prominent roles in Islamic fundamentalist movements has been played by Jamaah Islamiyah (JI). JI carries out its activities persistently, in particular in Southeast Asia, but also on an international level. Unfortunately, according to Hassan Hanafi, although Islam is a religion that is supposed to bring peace (the word Islam comes from the word "salam" which means "peace"), some radical Islamic groups and terrorist groups have interpreted their harsh and violent activities as being in the name of Islam.

Political Islam is a political institution which is oriented to promoting Islam as a way of life for a society and a political system for a country, and endeavours to implement Islamic law or Sharia in countries where the majority of the population is Muslim. Experts in
Indonesia agree that this term is an appropriate term to be used in Indonesia to replace the term Islamic fundamentalism (Istadiyantha, 2014). Political Islam is a political theory within an Islamic outlook, or the use of symbols and texts (nash) of the Islamic religion which revolve around social order, power, and authority (see previous Discussion). Whereas the Islamic political parties in Indonesia include Partai Persatuan Pembangunan (PPP), and a reference to political Islam is synonymous with a reference to Islamic parties such as Partai Keadilan dan Sejahtera (PKS) and Partai Bulan Bintang (PBB), while Islamic movements such asMajelis Mujahidin Indonesia (MMI) and Jamaah Ansharut Tauhid (JAT) are referred to as Islamic political movements (Hanafi, 1989).

After Muhammad bin Abdul Wahab (1701 - 1793) disseminated the Wahhabi ideology, which promoted the teachings of Islamic purism of Hanbal along the entire peninsula of Arabia, an Islamic reformist movement began to appear, which was better known as Salafism and spread to all corners of the world. The pioneers of this movement were reformist-modernist thinkers such as Jamaluddin al-Afghani, (1838-1935), Muhammad Abduh (1849-1905), and Muhammad Rasyid Ridha (1865-1935) who believed that rational thought, as the foundation of modern advancements, already existed in Islam. This movement made an important contribution to the ideas of modern Islam.

The origins of the organizations that are often referred to as New Islamic Movements can be traced back to the ideas of a number of Islamic movements in the Middle East ${ }^{5}$. Some of the movements which clearly imported their ideas from the Middle East are Gerakan Tarbiyah, Hizbut Tahrir Indonesia (HTI), and Salafi groups, including Lasykar 
Jihad Ahlussunnah wal Jama'ah. The ideas of the Tarbiyah movement are very similar to those of Ikhwanul Muslimun (IM), and this group even calls itself the "ideological child" of IM in Egypt. Hizbut Tahrir Indonesia is officially a branch of Hizbut Tahrir which is based in Jordan (Roy, 1996). DakwahSalafy, which includes Lasykar Jihad, is a community of activists from Salafi groups, and is associated with the network of Salafi movements in Saudi Arabia and the Middle East in generalRahmat. Originally, the Salafi agenda was to search for authenticity (the purification of Islam (Rahmat, 2005) and subsequently this agenda was translated into various concepts: Islamic morals, Islamic society, Islamic life views, Islamic countries, and Islamic Caliphates, as the ideas supported by Salafi groups ${ }^{6}$.Salafism is said to be a doctrine which teaches that Islamic teachings should emulate the behaviour of the Prophet Muhammad and his earliest followers ${ }^{6}$. The roots of Salafism can be traced back to the Wahhabi movement which first developed in Hejaz at the end of the $19^{\text {th }}$ century 6 . The characteristics of Islamic Political Movements are: a) To promote an Islamic textual civilization; b) To remain faithful to Sharia; c) To believe in the Western conspiracy theory that Muslims are their victims; d) To develop an agenda of anti-pluralism (Anwar, 2007).

\section{METHOD}

The theory used in this research study is the theory of diffusion. Diffusion is the spread of elements of a culture from one place in the world to another, either carried by groups of people who move from one place to another, or through a process of reporting through a medium of information. The analysis of the data is carried out deductively. The discussion of this topic makes use of various kinds of analysis which have the ability to present an accurate and real review, and for this reason, the technique of analysis is based on a triangulation of data, including written data; oral data (the results of interviews); and observation in the field, which is prepared as a tool for analysis that it is hoped will produce the best results.

\section{THE TRANSMISSION OF ISLAMIC POLITICAL MOVEMENTS FROM THE MIDDLE EAST TO INDONESIA}

The transmission of Islam to Indonesia took place with two different patterns: first, the pattern of trade and Sufism. In this pattern, Islam entered Indonesia through the social interaction that took place within the media of trade and religious teachings through the mystical ritual of tasawuf. Both of these media used the same cultural type, or in other words, elements of culture and tradition were the media of dissemination (Denys, 1996, Ngatawi, 2002).. Second was the pattern of radical fundamentalist political movements, or movements which were inclined to commit acts of violence in centres of power, and instil Islamic values by force while ignoring cultural factors ${ }^{9}$. These two patterns of movement formed the basis for subsequent movements.

There are two examples of developments of Islamic movements from the past which can be viewed as radical: In West Sumatra, the Padris declared that the followers of Tarekat Syattariyah and tasawuf, who had been around for centuries in Minangkabau, were people who were misguided polytheists and practised superstitious beliefs and acts of heresy, and should be suppressed (Fathurrahman, 2003). Tuanku Nan Renceh also pronounced Fakih Saghir, his friend and colleague from the same school, to be an infidel, giving him the title Raja Kafir and Rahib Tua, simply because he did not share the same religious views as Nan Renceh (Syaikhu, 2012). Secondly, the birth of Darul Islam and the Masyumi Party in Indonesia can be traced back to a connection with the network of Islamic movements in the 
Middle East, which in this case refers to the Wahhabi movement in Saudi Arabia and Ikhwanul Musliminin of Egypt, and in later times, the Hizbut Tahrir movement in Jordan (Bruinesen, 2002, Umar, 2010). In the 1980s, Indonesian students started to form more intense relations with Ikhwanul Muslimin activists in Egypt and Saudi Arabia (Rahmat, 2005) . A long time ago, there was even a connection between Muhammad Rasyidi andKaharMuzakkir (one of the people who signed the Jakarta Charter) who had once formed relations with Sayyid Quthub of Egypt, a prominent figure from Ikhwanul Muslimin (Istadiyantha, 2014). Muhammad Natsiralso formed broader relations with a number of Islamic countries (Rahmat, 2005). Under the leadership of Natsir, the Masyumi Party arranged for 90 Indonesian students to be sent to Egypt in 1957 (Rahmat, 2007).

Almost all of the colleagues of Usamah "Arab-Afghans" who came from Southeast Asia passed the recommendations and disposition of Abdullah Sungkar (Indonesian) who already had a special relationship with Abdurrasul Sayyafin Pakistan. In their discussions about ideology with Peshawar (Pakistan), the Indonesian mujahidin fighters proposed the idea ofan Islamic Army, DI/TII (Darul Islam/Tentara Islam Indonesia), led by Sekarmaji Marijan Kartosuwiryo, who was known as the founder of the Indonesian Islamic State or Negara Islam Indonesia (NII). This connection between Abdullah Sungkarand DI/TII was through Ajengan Masduki, until in 1993 they finally went their separate ways ideologically (Abegebriel, 2004).

The Indonesian contingent in Peshawar held discussions about the KanunAsasi (Basic Constitution) of NII, which consisted of 15 chapters and 34 sub-sections, as well as the KUHP NII which consisted of 10 chapters and 27 subsections (Abegebriel, 2004). All members of the contingent endeavoured to learn from each other and to establish a firmer ideological interaction through which they could move forward under the umbrella of "A Nation of God". Present at the meeting were members of various Islamic political movements from all over the world, ranging from Ikhwanu IMuslimun; Jamaa'ah Al-Jihad; AlJama'ah Al-Islamiyyahfrom Egypt, Morocco, Tunisia, and Pakistan; to Hamas and Hizbut Tahrir from Palestine; AtTakwirwal-Hijraor Jama'at Muslimin; MILF (Moro Islamic Liberation Front)Abu Sayyaf from the Philippines, DI/TII from Indonesia, and so on (Ibid.).

The history of the immigration or migration of HadhramautArabs (from South Yemen) to Indonesia in the $18^{\text {th }}$ century is thought to have been due to reasons of trade or commerce. Alwi Shihab disputes the opinion of expert historian Van den Berg, who states that the sole reason the Hadhramaut Arabs came to Indonesia was to seek wealth. Shihab believes that Berg's accusation is defamatory to the good name of Arabs (Shihab, 2004). Shihab's argument is founded on good reason because since the birth of Islam, Arabs have never been free from conspiracies put forward by outsiders who have a wish to discredit Islam. It is no secret that some of the information that developed in Indonesia was the result of an effort by Dutch colonial powers to stem the influence of Islam from Arabic nations. To the Dutch, Islam was a threat to their existence in Indonesia (Shihab, 2004).

The book entitled Negara Tuhan: The Thematic Encyclopaedia (Abegebriel, 2004) presents the opinion of The Indonesian Moslem Scholars Community (IMS.Com), namely that: a) The international network of radicalism by the name of Alqaidah and Al-Jama'ah AlIslamiyah was the result of verbalistic and scripturalistic ideas about religious texts which were forced to legitimize violent acts through jihad and spread terror "in the name of God" and as "the agenda of the Prophet" (Abegebriel, 2004). 
The transmission of Islamic political movements to Indonesia has seen rapid developments since the 1970s and 1980s. This transmission was influenced by a greater intensity in relations which occurred in the 1970s and 1980s (as a result of the boom in world oil prices which enabled oil producing countries such as Saudi Arabia to offer more opportunities for foreign students to earn scholarships to continue their studies in Arabic countries). Since 1975, DDI (Dewan Dakwah Islamiyah) began to hold a central position as a mediator which channelled funds from Rabithah Alam Islami in Saudi Arabia to Indonesia. These funds were given to various Islamic organizations such as NU, Muhammadiyah, and al-Irsyad to pay for students who wished to study in the Middle East (Hasan, 2012).

Abdul Munip offers a different opinion from that suggested in studies by Azra and Van Bruinesssen (Munip, 2007), (Azra, 2000), namely that in addition to the transmission of knowledge from the Middle East to Indonesia that has taken place for centuries through the contact of religious leaders, there is also another phenomenon that is interesting to study, namely the translation of Arabic books from the Middle East into the Indonesian language. According to Munip, the existence of books that have been translated from Arabic to Indonesian has both a positive and negative effect (Munip, 2007). The positive effect is that it increases the availability of books of literature that can be easily accessed by Indonesian Muslims. The negative effect, however, is that: a. these translated books cannot be separated from the time setting and the social, cultural, and historical conditions of the Middle East, as the home of the writer; $b$. there are often mistakes or inaccuracies in the translations and as a result, these translated books fail to transmit the content of the original books. The consequence of this is that it is quite probable that a transfer of teaching or doctrine may occur which cannot be adapted to suit the socio-historic character, and this leads to a concern that the transfer of knowledge from the Middle East may ultimately turn into a form of Arabization. Up to the present time, there is no official government institution which monitors the quality of translations from Arabic to Indonesia (Ibid.). Abdul Munip also brings to light a recent situation in which there has been an increase in the spirit of fundamentalism among some Indonesian Muslims. One of the indicators of this is the open emergence of social and political movements which have their own somewhat radical perspectives and ways, calling on Muslims to follow their religion perfectly (kaaffah) and also calling for the formal implementation of sharia law in Indonesia. This ideology is similar to the ideology that had developed previously in the Middle East (Ibid.).

Noorhaidi Hasan (2012) states that: 1) Political Islam has developed as a dynamic of the existing power struggle. In many ways it is a public protest that is disguised in the form of religious symbols and discourse. In the midst of the domination of the secular political system of the West, political Islam encourages the Islamic religion to enter into the field of discourse, and in the circle of power of the state to become a system which regulates all systems of life. A developmental milestone in political Islam occurred following the defeat of the Arabic world to Israel in 1967. The loss of this war caused many Muslims to become more aware of how fragile the regimes in their countries were; 2) From this perspective, it can be seen clearly that political Islam developed over the defeat of these regimes. Political Islam is not a story of success but rather a series of episodes of defeat which often end with fragmentation or paralysis as a result of the brutal repression of the state; 3) The ups and downs in political Islam cannot be separated from the geo-strategic constellation that has occurred in the 
world of Islam. The influence of alIkhwan began to spread to a number of different countries in the 1970s, at first riding on the coat-tails of the ambitious campaign of Saudi Arabia to export Wahhabism in an endeavour to strengthen the geo-strategic position of the centre of the Islamic world, and this included the protection of a group of prominent alIkhwan members who fled from Egypt to Saudi Arabia following the execution of Quthb and his allies; 4) The surge in oil prices in the 1970s gave the opportunity for Saudi Arabia to fill the ideological vacuum that had occurred as a result of the defeat in the war against Israel in 1967 and had led to a decline in socialist nationalism in Egypt during the era of Naser. Saudi Arabia was able to facilitate various educational and proselytizing activities all over the world. Saudi Arabia used Rabithah Alam Islami as a media for cooperation both on a local and international level; 5) The Iranian Revolution in 1979 which resulted in Iran becoming an Islamic State was the blueprint for the only example of tactics that were successful in revolutionary Islamism; 6) The war in Afghanistan allowed opportunities for various Muslim activists from all over the world to come together and act as volunteers in jihadi activities. This included the activities of Al-Qaeda, led by Osama bin Laden, which endeavoured to show resistance to Iraq but was rejected by Saudi Arabia. The protests led by bin Laden marked the emergence of Salafi jihadists (Hasan, 2012).

During the Suharto era, a Komando Jihad (Komji) was created by the New Order government in order to give the impression that the Indonesian government was under threat from extremist right-wing groups, after it had previously succeeded, in 1965, in managing to quash the threats of the extremist left-wing communist party, PKI (Yunanto et al., 2003). The method used by Ali Murtopo, head of Bakin (Badan Koordinasi Intelejen Negara or the State
Intelligence Coordination Body) to detect activists from organizations such as NII, DI, and TII, was to recruit DI activists who had been released from prison in the 1960s. With the goal of suppressing the Indonesian Communist Party (PKI), these DI activists were nurtured and coached by the State Intelligence Coordination Body (BAKIN) until PKI was finally disbanded. The coaching and nurturing of these DI activists led to the birth of the "Komando Jihad" movement (Yunanto, 2003).

The ideology of Al-Qaeda that had been carried by Osama bin Laden for the previous five years failed to attract much attention, especially following the rumours that bin Laden had been shot dead by soldiers from the USA Navy Seals on 1 May 2011, in Abbottabad, Pakistan. Bin Laden's ideology also adopted the ideas of Al-Ikhwan, including Hizbut Tahrir which was a splinter group of Al-Ikhwan. In 2011, Abdurrahman AlBagdadi separated himself from 1-Qaeda and formed ISIS, and this movement attracted the attention of Arabic youths, many of whom joined the movement, as well as young people in Indonesia. There has been a rapid transmission of this ideology throughout the whole world, and especially to Indonesia. The way in which ISIS has used social media and propaganda to reach the young generation is not unrelated to its ability to play a secondary role such as it did at the time of the Arab Spring. The role of social media and the young generation was a significant factor in the mobilization of a social movement to overturn the regime. It has been this power of the social media and the young generation that has been used by ISIS to support its militant forces. The use of social media in the framework of recruitment, propaganda, and the dissemination of information to various networks across the entire world is extremely effective (Syauqillah, 2015).

The declaration of support by ISIS sympathizers at the Hotel Indonesia roundabout in March 2014 was an important moment for witnessing the 
extent of the Indonesian people's support for ISIS. There are at least two main currents in the way that factions of radical Islamic movements in Indonesia have responded to the declaration of a caliphate by ISIS: the faction that rejects ISIS and the faction that accepts ISIS. These two main currents follow the conflict between ISIS and Al-Qaeda. As we are aware, in the past, radical Islamic movements in Indonesia have followed the leadership of Al-Qaeda. In response to the declaration by Abu Bakar Al-Baghdadi, there was a polarization of factions. Interestingly, the faction that rejects ISIS may also send its sympathizers to Syria. The conflict between ISIS and Al-Qaeda has also had other implications, namely that the migration of Indonesian citizens has in general led them to join ISIS and the militant wing of Al-Qaeda, JabhahNusrah. In simple terms, the recruitment of a network of ISIS sympathizers in Indonesia follows two main currents (Syauqillah, 2015). Firstly, recruitment via existing networks, or networks that are affiliated with Abu Bakar Baasyir. Secondly, recruitment through social media. Amongst the old network of radical Islamic movements in Indonesia which include ISIS sympathizers, the name Abdul Rauf appears. Previously convicted for his involvement in the Bali bombings, for being part of the Banten circle, and for robbing a gold shop to fund the Bali bombings, Rauf was released from prison in 2011. In addition to Rauf, another name that has appeared is that of Muslim clericAfif Abdul Majid, a veteran of Afghanistan, who was sentenced to 4 and a half years in prison by the District Court in Central Jakarta after being found guilty of helping to fund organizations affiliated to ISIS. In response to the verdict, Afif announced that he would submit an appeal. In addition to these two names, there are still several other people who have contributed to the development of ISIS in Indonesia.

\section{CONCLUSIONS}

The Islamic Political Movements that have developed in Indonesia are developments of the Islamic Political movements that exist in the Middle East and the ideas adopted from the Middle East are those of Al-Ikhwan, JI, and Salafism. Laskar Jihad adopted the ideas of Salafi leaders from Saudi Arabia and especially Yemen. FPIS and LUIS are two local Islamic movements that are unique to the city of Solo. They have not adopted Arabic attributes such as the use of tunics, although their ideas about aqidah and sharia in general are dominated by those of Manhaj Salafi with its program to purify the teachings of Islam and to eradicate immorality.

\section{RECOMMENDATIONS}

The Indonesian government needs to keep a closer watch on students, workers, and immigrants entering and leaving the Indonesian Republic in order to ensure that outside ideologies are not brought into the country which may pose a threat to the Indonesian people.

\section{REFERENCES}

Anwar, M. S. (2007). Memetakan Teologi Politik dan Anatomi Gerakan Salafi Militan di Indonesia. In M. Z. Mubarak, Genealogi Islam Radikal di Indonesia: Gerakan, Pemikiran, dan Prospek Demokrasi. Jakarta: LP3ES.

Abegebriel, A. M., Abeveiro, A. Y., \& Team, S.-I. (2004). Negara Tuhan: The Thematic Encyclopaedia. Yogyakarta: SR-Ins Publishing.

Abegebriel, A. M. (2004). Ada Apa dengan Dokumen JI. In A. M. Abegebriel, A. Y. Abeveiro, \& S.-I. Team, Negara Tuhan: The Thematic Encyclopaedia. Yogyakarta: SR-Ins Publishing.

Azra, A. (2000). Islam Substantif: Agar Umat Tidak Jadi Buih. 
Bandung: Penerbit Mizan.

Bruinesen, M. v. (2002). Genealogies of Islamic Radicalism in PostSoeharto Indonesia. South East Asia Research, 10.

Denys, L. (1996). Nusa Jawa Silang Budaya (Vols. 1-3). Jakarta: PT Gramedia Pustaka Utama.

Fathurrahman, O. (2003). Tarekat Syattariyah di Dunia MelayuIndonesia: Kajian atas Dinamika dan Perkembangannya Melalui Naskah-naskah di Sumatera Barat. Dissertation. Jakarta: Roy, O. (1996). Gagalnya Politik Islam. (French language edition entitled: L'echec de l'islampolitique, Edition $d u$ Seuil, 1992; and English language edition entitled The Failure of the Political Islam, Harvard University Press). Jakarta: Serambi.

Hasan, N. (2012). Islam Politik di Dunia Kontemporer: Konsep, Genealogi, dan Teori. Yogyakarta: UIN Sunan Kalijaga Press.

Hanafi, H. (1989). Al-Ushüliyyah AlIstāmiyyah in Ad-Dīnwa 'tsTsaurah. 6.

Istadiyantha. Radical Islamic Movement and Terrorism in Indonesia: The Study of National Integraion Effort. Universitas Indonesia International Seminar of the Middle East: The Dynamics of the Middle East Culture after Arab Spring. Jakarta: FIB Universitas Indonesia.

Istadiyantha. (2014). Transmisi Gerakan Islam Politik dari Timur Tengah ke Indonesia. Dissertation. Yogyakarta: Postgraduate Faculty Universitas Gadjah Mada.
Jamhari, \& Jahroni, J. (2004). Gerakan Salafi Radikal di Indonesia. Jakarta: Raja Grafindo Persada.

Munip, A. (2007). Transmisi Pengetahuan Timur Tengah ke Indonesia: Studi tentang Penerjemahan Buku Berbahasa Arab di Indonesia Periode 1950-2004. Dissertation. Yogyakarta: Postgraduate Programme UIN Sunan Kalijaga.

Ngatawi. (2002). Radikalisme Gerakan Islam Simbolik FPI. Thesis. Jakarta: Postgraduate Programme Universitas Indonesia.

Syaikhu, A. (2012). Pergulatan Organisasi Islam dalam Membendung Gerakan Ideologi Islam Transnasional. Jurnal Falasifa, 3 (1).

Umar, A. R. (2010). Melacak Akar Radikalisme Islam di Indonesia. Jurnal Ilmu Sosial dan Ilmu Politik, 4 (2).

Rahmat, M. I. (2005). Arus Baru Islam Radikal: Transmisi Revivalisme Islam Timur Tengah ke Indonesia. Jakarta: Penerbit Erlangga.

Shihab, A. (2004). Keturunan Arab adn Radikalisme Indonesia. In $\mathrm{T}$. Thahir, Meredam Gelombang Radikalisme. Jakarta: CMM.

Syauqillah, M. (2015). Indonesian Sympathizers and International Relations. Universitas Indonesia International Seminar of The Middle East: The Dynamics of the Middle East Culture after Arab Spring. Jakarta: FIB Universitas Indonesia.

Yunanto, Nuryanti, S., Hasjim, J. F., Effendy, R. F., Anggoro, K., Basman, T. M., et al. (2003). Gerakan Militan Islam: di 
Jurnal CMES Volume XI Nomor 2 Edisi Juli-Desember 2018

Program Studi Sastra Arab FIB UNS Surakarta

Indonesia dan di Asia

Tenggara. Jakarta: Friedrich-

Ebert-Stiftung (FES) dan The

Ridep Institute. 